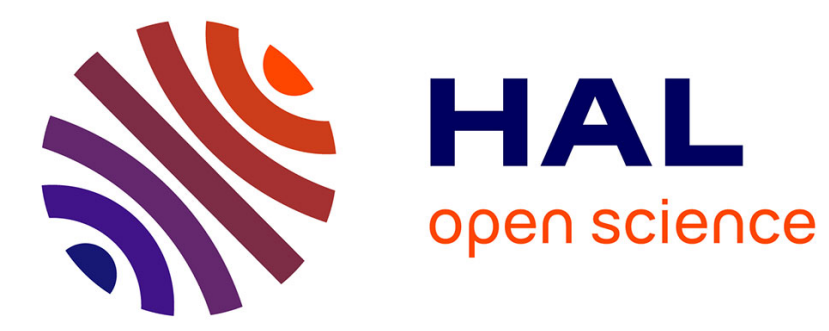

\title{
Stresses in compressed bubble rafts
}

Christophe Ybert, Jean-Marc Di Meglio

\section{To cite this version:}

Christophe Ybert, Jean-Marc Di Meglio. Stresses in compressed bubble rafts. Comptes Rendus. Physique, 2002, 3 (4), pp.555 - 559. 10.1016/S1631-0705(02)01340-3 . hal-01628742

\section{HAL Id: hal-01628742 \\ https://hal.science/hal-01628742}

Submitted on 4 Nov 2017

HAL is a multi-disciplinary open access archive for the deposit and dissemination of scientific research documents, whether they are published or not. The documents may come from teaching and research institutions in France or abroad, or from public or private research centers.
L'archive ouverte pluridisciplinaire HAL, est destinée au dépôt et à la diffusion de documents scientifiques de niveau recherche, publiés ou non, émanant des établissements d'enseignement et de recherche français ou étrangers, des laboratoires publics ou privés. 


\title{
Stresses in compressed bubble rafts
}

\author{
Christophe Ybert $^{a}$, Jean-Marc di Meglio ${ }^{\text {b,c* } *}$ \\ a Centre de recherche Paul Pascal (CNRS UPR 8641), avenue Albert Schweitzer, 33600 Pessac, France \\ b Institut Charles Sadron (CNRS UPR 22), 6, rue Boussingault, 67083 Strasbourg cedex, France \\ c Université Louis Pasteur and Institut Universitaire de France
}

Received 16 November 2001; accepted after revision 21 March 2002

Note presented by Pierre-Gilles de Gennes.

\begin{abstract}
We present a simple geometric method to determine the stress field in a compressed bubble raft. We show that bubble rafts exhibit arches phenomena as do granular materials, and examine the relaxation of stresses following a $T_{1}$ transformation. To cite this article: C. Ybert, J.-M. di Meglio, C. R. Physique 3 (2002) 555-559. () 2002 Académie des sciences/Éditions scientifiques et médicales Elsevier SAS
\end{abstract}

bubble raft / foams / granular materials

\section{Contraintes dans un radeau de bulles en compression}

Résumé Nous présentons une méthode géométrique simple pour déterminer le champ de contraintes dans un radeau de bulles. Nous mettons ainsi en évidence l'existence d'arches très similaires à celles existant dans les milieux granulaires. Nous étudions aussi de manière succincte la relaxation des contraintes lors d'une transformation $T_{1}$. Pour citer cet article $:$ C. Ybert, J.M. di Meglio, C. R. Physique 3 (2002) 555-559. (C) 2002 Académie des sciences/Éditions scientifiques et médicales Elsevier SAS

radeau de bulles / mousses / matériaux granulaires

\section{Version française abrégée}

Les matériaux granulaires sont à la mode depuis quelques années parmi les physiciens. Ces matériaux, tels que le sable, peuvent avoir un caractère solide [1] avec la formation de remarquables arches de force, mais aussi un caractère liquide en coulant (sablier) avec des profils de vitesse fortement non-newtoniens (existence de bandes de cisaillement [2]). Les mousses aqueuses sont des matériaux cellulaires particuliers qui présentent des similitudes avec les matériaux granulaires, avec par exemple l'existence d'avalanches [4], d'écoulement inhomogène [5,6] et de bandes de cisaillement [7]. Un des défis expérimentaux posés par les matériaux granulaires est de pouvoir visualiser leur structure interne. Dans cette note, nous présentons une méthode très simple de traitement d'image qui permet d'obtenir le champ de force de mousses aqueuses bidimensionnelles comprimées.

Nous avons utilisé de l'eau et un détergent commercial pour fabriquer un radeau de bulles [8] à la surface d'une cuve de dimensions $\left(10 \times 112 \times 212 \mathrm{~mm}^{3}\right)$. Le diamètre des bulles est environ égal à $5 \mathrm{~mm}$. Grâce

\footnotetext{
* Correspondence and preprints.

E-mail addresses: ybert@ crpp.u-bordeaux.fr (C. Ybert); dimeglio@ ics.u-strasbg.fr (J.-M. di Meglio).
} 


\section{Ybert, J.-M. di Meglio / C. R. Physique 3 (2002) 555-559}

à une barrière mobile posée sur la cuve, on peut faire varier la surface de celle-ci et comprimer le radeau. La Fig. 1 représente l'image d'un radeau de bulles (a), image binarisée en (b). Tous les traitements d'image ont été réalisés avec le logiciel NIH Image [9].

Le champ de force dans les radeaux de bulles est déterminé de la manière suivante (Fig. 2) : la forme de chaque bulle est ajustée par une ellipse de demi-axes $a$ et $b$; on remplace chaque bulle dans l'image de départ par un segment de droite de longueur $l=(a-b) / a$ et orienté selon la direction de la déformation. La Fig. 3 représente ainsi le champ de force dans un radeau avant (a) et après (b) compression de la surface de $26 \%$. On remarque aisément :

- la présence de lignes de force dirigées selon la direction moyenne de compression, mais ces lignes contournent les régions de défauts de la structure pour former des arches;

- un des inconvénients de la méthode est qu'elle ne détecte évidemment que les anisotropies du champ de force : une bulle libre et une bulle comprimée isotropiquement sont représentées de la même manière par un point;

- les murs délimitant le radeau de bulles n'affectent qu'une seule rangée de bulles.

Pour illustrer les possibilités de notre méthode, Fig. 4 montre les modifications du champ de force engendrées par la migration d'un cœur de dislocation en une succession d'évènements $T_{1}:$ la déformation du champ de force autour du défaut initialement en haut de (a) est relaxée tandis que le défaut vient se piéger près d'un défaut associé à un vecteur de Burgers de signe opposé (b). Nous n'avons pas observé d'annihilation de paires de défauts pour obtenir un résau hexagonal parfait.

La méthode proposée devrait pouvoir permettre de prédire l'évolution d'une mousse 2D à partir des déviations du champ de force par rapport à un réseau en nid d'abeille et aidera certainement à parfaire les simulations numériques de déformation de mousses.

\section{Introduction}

Granular materials have been receiving a lot of attention from physicists during the last ten years. These materials exhibit striking features as compared to conventional materials (solids or liquids); the most remarkable features are force arches in their solid state [1] and inhomogeneous flows and shear banding [2] as they flow. Foams [3] represent another class of cellular materials that present very similar cooperative phenomena of avalanches [4], inhomogeneous flow [5,6] and shear banding [7]. They provide moreover a control of the dynamic correlation between their constitutive elements (bubbles) $[4,7]$ through the modulation of their water content. One important direction of investigation of cellular materials is devoted to the development of new techniques of imaging since these materials are essentially opaque because of light absorption (sand) or multiple light scattering (aqueous foams). Two-dimensional (2D) aqueous foams and bubble rafts [8] offer the possibility of direct optical imaging. In this note, we present some experiments of compression of a bubble raft where a simple image analysis can provide the force field.

\section{Experiments, method and results}

We have used a common dish-washing liquid dissolved in water to make a bubble raft by blowing air (using a small pump) through a capillary tube in a $10 \times 112 \times 212 \mathrm{~mm}^{3}$ trough. Bubbles were fairly monodisperse with a diameter of about $5 \mathrm{~mm}$. The surface area of the raft can be changed by displacing a barrier disposed on the trough which actually is then very similar to a classical Langmuir trough. Figure 1 presents a bubble raft image taken by a video camera just above the trough (a) and then binarized (b), taking advantage of the good optical contrast. All image processing has been performed with NIH Image software [9]. 




(a)

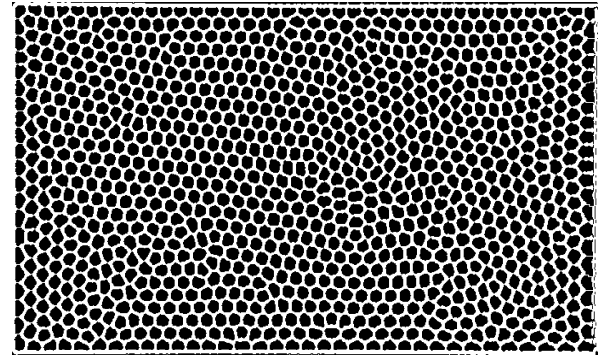

(b)

Figure 1. (a) Image of a bubble raft, (b) binarization. The diameter of an individual bubble is about $5 \mathrm{~mm}$.

Figure 1. (a) image d'un radeau de bulles, (b) après binarisation. Le diamètre des bulles est égal à environ $5 \mathrm{~mm}$.

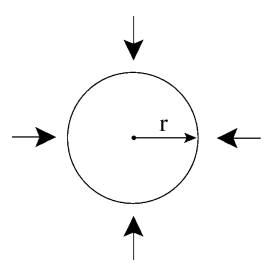

(a)

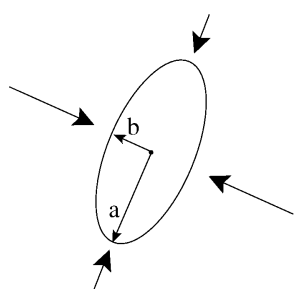

(b)

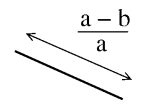

Figure 2. Schematic representation of a bubble. (a) the bubble is submitted to an isotropic force field (pressure), it is spherical and the force will be represented by a simple dot. (b) the bubble is distorted by an anisotropic force field into an ellipse of semi-axes $a$ and $b$, the stress field will be represented by a line segment of length $l=(a-b) / a$ and oriented along the axis of maximal compression.

Figure 2. Représentation schématique d'une bulle. (a) la bulle est soumise à un champ de force isotrope (pression), elle est sphérique et la force locale associée sera représentée par un simple point, (b) la bulle est déformée dans un champ de force anisotrope en une ellipse de demi-axes a et $b$, la force locale est représentée par un segment de droite de longueur $l=(a-b) / a$ orienté selon la direction de compression maximale.

Our primary goal in this study was to investigate $2 \mathrm{D}$ avalanches of bubble bursts triggered by the compression of the raft. It happened that we were not able to produce original results on avalanche onset using compression: avalanches only occur in unstable foams (i.e. with a small quantity of surfactant [4]) for which the compression does not seem to play any significant role. When using stable foams, it appears that the monolayer configuration is less stable, with respect to a compression stress, than individual bubbles. Therefore the compression stress is released by expelling bubbles out of the monolayer, thus inducing the formation of multilayers of bubbles and a collapse up in the third dimension, rather than by the bursting of bubbles. Nevertheless, it appeared to us that the determination of the force field as explained below may bring some new information on the physics of foams.

We have fitted each binarized bubble (Fig. 1(b)) by an ellipse of semi-axes $a$ and $b$ and describe the deformation of each bubble by a line segment of length $l=(a-b) / a$ oriented along the deformation (Fig. 2). $2 a$ and $2 b$ are not very different from the maximum and minimum so-called Feret's diameters of each individual bubble. $l$ is very sensitive to small deformations on the contrary of a common parametrization of the deformation defined by $p / \sqrt{A}$ where $p$ is the perimeter of the object and $A$ its area; in addition it provides information on the direction of the deformation [10]. Figure 3 shows the force 


\section{Ybert, J.-M. di Meglio / C. R. Physique 3 (2002) 555-559}

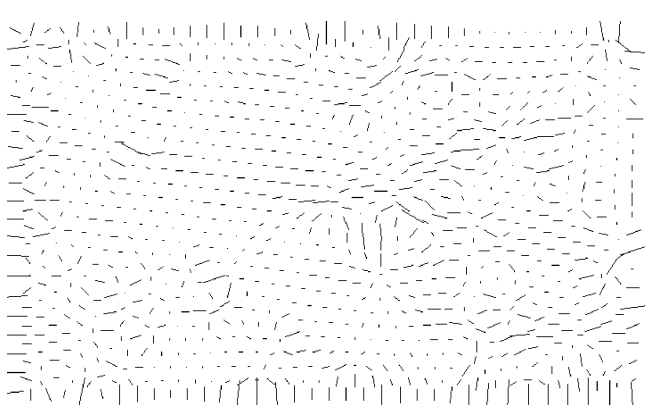

(a)



(b)

Figure 3. Force field in a bubble raft, (a) before compression, (b) after compression.

Figure 3. Champ de force dans un radeau de bulles, (a) avant compression, et (b) après compression.

field of a bubble raft before (a) and after compression (b) (the compression ratio is 1.26 and the velocity of the mobile barrier was $0.18 \mathrm{~mm} \cdot \mathrm{s}^{-1}$ ).

Several interesting features can be distinguished and deserve some comments:

- The main feature is that we can naturally distinguish force lines directed along the direction of compression, but these force lines are bent around the defects of the raft and form arches-like structures. These arches become more evident and pronounced after compression.

- A serious drawback of the method of stress determination is that it cannot give the pressure component (i.e. the isotropic term) of the force field; bubbles under pressure or free bubbles will be represented by dots on the force field map. In the present system, the isotropic term is not easy to get: the area $A$ of the bubble is not readily related to the pressure because the bubble is free to distort in the vertical (unseen) direction. It is nevertheless possible to get an estimate of this pressure if we assume for instance that a spherical bubble deforms into a cylinder capped by two hemispheres under compression: we obtain that the pressure in the raft of Fig. 3(b) is about $2 \mathrm{~Pa}$ which is of the same order of magnitude as the value of $5 \mathrm{~Pa}$ measured experimentally on the raft using a pressure transducer. Such low pressure values ensure that the volume of gas remains unchanged during the compression.

- We can easily see the confinement effect of the borders of the trough on the raft; it is interesting to notice that only one layer of bubbles seems to be affected by the confinement.

Finally, we present on Fig. 4 the modification of the force field after the displacement of a defect inside the raft through a succession of $T_{1}$ events. The displacement of the defect has been triggered by compression ((a) and (b) have been rescaled to eliminate the force components due to the compression terms, the velocity of the mobile barrier was $0.18 \mathrm{~mm} \cdot \mathrm{s}^{-1}$ ). The defect at the top of (a) is accompanied (like for all defects) by a deformation of the force field. This deformation is relaxed in (b) after the defect moved to the lower bottom part of (b) and get trapped in the vicinity of another defect. A dislocation is associated to the formation of a pair of defects with coordinence 5 and 7 as sketched on Fig. 4(c). Note that the observed displacement (glide) of defect then leads to the pairing of two dislocations of opposite Burgers vectors; we have not observed the annihilition of a pair of dislocations which should thus be associated with a very high activation energy. The displacements of dislocations are very rare events and are driven by the compression of the raft. A recent published study of bubble rafts also reports that 5-7 defect motions do not occur spontaneously on bounded rafts [11].

\section{Conclusion}

We have described a simple geometrical method to obtain the force field acting on a bubble raft. We have shown the formation of force arches in compressed bubble rafts that supports the idea of an analogy 


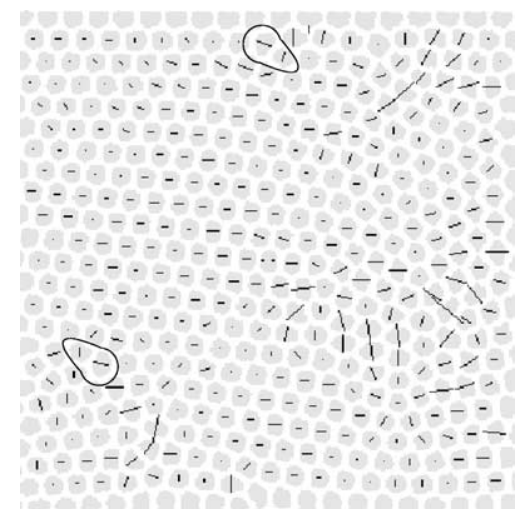

(a)

Figure 4. Representation of the force field superimposed with the raft structure before (a) and after (b) the displacement of a dislocation. (c) A dislocation introduces defect cells with 5 and 7 coordinence.

Figure 4. Représentations superposées du champ de force et de la structure du radeau. (a) Avant déplacement de la dislocation et $(\mathrm{b})$ après déplacement de celle-ci.

(c) La présence d'une dislocation introduit une paire de cellules-défauts avec 5 et 7 voisines au lieu de 6.

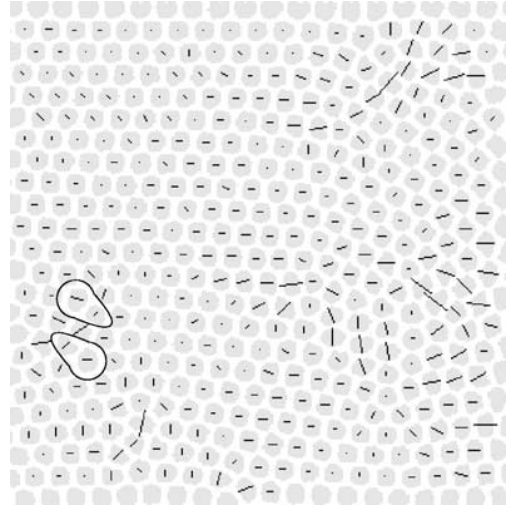

(b)

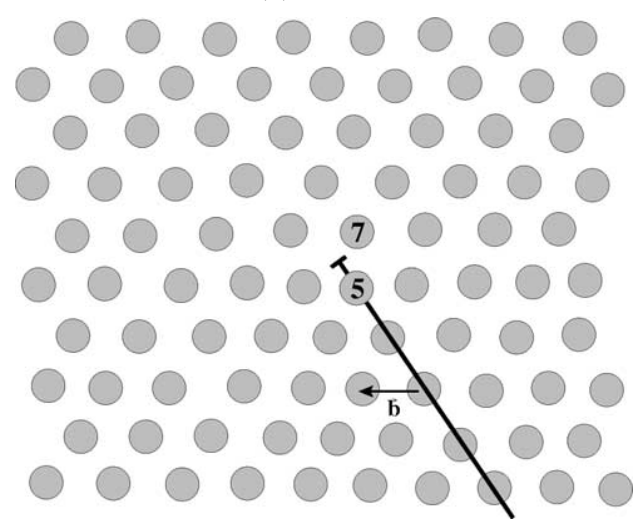

(c)

between aqueous foams and granular materials. Finally, we have shown the relaxation of the stresses that comes together with the motion of a dislocation within the raft.

\section{References}

[1] J. Duran, Sable, poudres et grains, Eyrolles, Paris, 1997.

[2] D. Mueth, G. Debrégeas, G. Karczmar, S. Nagel, H. Jaeger, Nature 406 (2000) 385-389.

[3] D. Weaire, F. Bolton, T. Herdtle, H. Aref, Philos. Mag. Lett. 66 (1992) 293-299.

[4] W. Müller, J.-M. di Meglio, J. Phys. Cond. Matt. 11 (1999) L209-L215.

[5] S.A. Langer, A.J. Liu, J. Phys. Chem. B 101 (1997) 8667-8671.

[6] Hébraud, F. Lequeux, J.-P. Munch, D.J. Pine, Phys. Rev. Lett. 78 (1997) 4657-4660.

[7] G. Debrégeas, H. Tabuteau, J.-M. di Meglio, Phys. Rev. Lett. 87 (2001) 178305.

[8] L. Bragg, J.F. Nye, Proc. Roy. Soc. London A 190 (1947) 474-481.

[9] http://rsb.info.nih.gov/nih-image/.

[10] For small deformations, $l$ is related to the stresses $\sigma_{x x}$ and $\sigma_{y y}$ along the principal directions of deformations $x$ and $y$ by $l \simeq\left(\sigma_{x x}-\sigma_{y y}\right) /(2 \mu)$ where $\mu$ is the shear modulus.

[11] T. Tam, D. Ohata, M. Wu, Phys. Rev. E 61 (2000) R9-R12. 